\title{
Pengaruh Likuiditas, Kebijakan Hutang, Pertumbuhan Perusahaan dan Ukuran Perusahaan Terhadap Nilai Perusahaan dengan Profitabilitas Sebagai Variabel Intervening pada Perusahaan Sub Sektor Farmasi Di Bursa Efek Indonesia Periode 2014 - 2019
}

\author{
Suryanti, Arna Suryani*, Yunan Surono \\ Magister Manajemen Universitas Batanghari \\ *Correspondence email: arna_halim@yahoo.co.id
}

\begin{abstract}
Penelitian ini untuk melihat pengaruh Pengaruh Likuiditas, Kebijakan Hutang, Pertumbuhan Perusahaan Dan Ukuran Perusahaan Terhadap Nilai Perusahaan Dengan Profitabilitas Sebagai Variabel Intervening Pada Perusahaan Sub Sektor Farmasi Di Bursa Efek Indonesia Periode 2014 - 2019. Variabel likuiditas yang diproxykan dengan current ratio, kebijakan hutang yang diproxykan dengan debt to equity ratio, pertumbuhan perusahaan yang diproxykan dengan perubahan total aset dan ukuran perusahaan yang diproxykan dengan logaritma normal $(\mathrm{Ln})$ penjualan terhadap nilai perusahaan yang diproxykan dengan price to book value dengan profitabilitas yang diproxykan dengan return on equity sebagai variabel intervening. Sampel penelitian yang digunakan adalah Sub Sektor Farmasi Di Bursa Efek Indonesia selama 6 tahun periode pengamatan, dimulai dari tahun 2014 - 2019 tercatat sebanyak 10 perusahaan, yang memiliki laporan keuangan yang lengkap dan yang memiliki laporan indikator penelitian yang lengkap dalam laporan keuangan tahunan selama periode penelitian sebanyak 8 perusahaan. Penelitian ini menggunakan teknik purposive sampling dan analisis data menggunakan bantuan software microsoft Excell dan SPSS 22.0. dengan Path Analysis. Hasil penelitian menunjukkan bahwa; 1) Secara simultan seluruh variabel bebas tidak berpengaruh segnifikan terhadap variabel terikat sedangkan bahwa secara parsial hanya variabel pertumbuhan perusahaan yang diproxykan dengan perubahan total aset yang berpengaruh terhadap variabel profitabilitas. 2) Secara simultan seluruh variabel bebas berpengaruh signifikan terhadap variabel terikat sedangkan secara parsial hanya variabel pertumbuhan perusahaan yang diproxykan dengan perubahan total aset yang tidak berpengaruh terhadap variabel nilai perusahaan. 3) Variabel profitabilitas yang diproxykan dengan return on equity tidak berpengaruh terhadap variabel nilai perusahaan yang diproxykan dengan price to book value. 4) Variabel likuiditas, kebijakan hutang, pertumbuhan perusahaan dan ukuran perusahaan terhadap nilai perusahaan dengan profitabilitas sebagai variabel intervening mempunyai pengaruh total sebesar $11,1838 \%$, yang besar pengaruhnya termasuk lemah.
\end{abstract}

Kata Kunci : Likuiditas, Kebijakan Hutang, Pertumbuhan Perusahaan, Ukuran Perusahaan, Nilai Perusahaan, Profitabilitas dan Variabel Intervening.

Abstract: This study is to look at the influence of Liquidity, Debt Policy, Company Growth And Company Size on Company Value With Profitability As Intervening Variable In Pharmaceutical Sub-Sector Companies on Indonesia Stock Exchange Period 2014 2019. Liquidity variables that are diproxykan with current ratio, debt policy that is diproxykan with debt to equity ratio, growth of the company that is diproxykan with changes in total assets and the size of the company that is diproxykan with normal logarithm (Ln) sales to the value of the company that is mortgaged with price to book value with profitability diproxykan with return on equity as intervening variables. The research sample used is the Pharmaceutical Sub Sector on the Indonesia Stock Exchange during the 6-year observation period, starting from 2014 - 2019 recorded as many as 10 companies, which have a complete financial report and which have a complete research indicator report in the annual financial report during the research period as many as 8 companies. This study used purposive sampling and data analysis techniques using the help of microsoft Excell and SPSS 22.0 software. with Path Analysis. The results showed that; 1) Simultaneously all free variables have no effect on bound variables whereas that partially only the growth variables of the company are diproxykan with changes in total assets that affect the variable profitability. 2) Simultaneously all free variables have a significant effect on bound variables whereas partially only the growth variables of the company are diproxykan with changes in total assets that have no effect on the variable value of the company. 3) Variable profitability diproxykan with return on equity has no effect on the variable value of the company that is diproxykan with price to book value. 4) Variable liquidity, debt policy, company growth and the size of the company to the value of the company with profitability as an intervening variable has a total influence of $11.1838 \%$, the large influence including weak.

Keywords: Liquidity, Debt Policy, Company Growth, Company Size, Company Value, Profitability and Intervening Variables.

\section{Pendahuluan}

Persaingan bisnis yang semakin ketat dalam industri farmasi setelah diberlakukannya Jaminan Kesehatan Nasional (JKN), yang menuntut setiap perusahaan untuk berlomba dengan meningkatkan produksi obat-obatan terutama obat generik, alat kesehatan dan produk-produk kesehatan terkait, seperti masker, sanitizer dan lainnya seiring peningkatan permintaan dengan adanya program JKN maupun wabah covid 19. Perusahaan-perusahaan sektor industri farmasi akan terus dan berupaya untuk melakukan pengembangan usaha guna menghadapi persaingan yang semakin ketat, sehingga akan diperlukan investasi yang besar dan manajemen yang efektif dan effisien. Kinerja 
Suryanti, Arna Suryani dan Yunan Surono, Pengaruh Likuiditas, Kebijakan Hutang, Pertumbuhan Perusahaan dan Ukuran Perusahaan Terhadap Nilai Perusahaan dengan Profitabilitas Sebagai Variabel Intervening pada Perusahaan Sub Sektor Farmasi Di Bursa Efek Indonesia Periode 2014 - 2019

perusahaan dapat dilihat dari perkembangan perusahaan, neraca perusahaan dan laporan laba ruginya, proyeksi usaha dan rencana perluasan dan kerjasama, terutama dari laporan keuangan yang diterbitkannya, dan dari laporan keuangan emiten, maka dapat dilihat kinerja keuangannya, baik dari segi kemampuan menghasilkan keuntungan (profitabilitas), kemampuan membayar hutang (likuiditas), struktur modalnya (leverage), maupun tingkat efisiensi dan efektifitasnya dalam mengelola kekayaannya (aktivitas) maupun kinerja pasarnya. Jika perusahaan yang mengeluarkan saham dalam kondisi yang baik kinerjanya, harga saham akan cenderung meningkat. sehingga kepercayaan investor kepada emiten semakin baik, investor mempunyai harapan akan memperoleh laba bersih yang besar sehingga bagian keuntungan atau dividen yang diperoleh juga besar.

Penelitian ini akan menggunakan variabel bebas pertama (X1) berupa likuiditas yang diproxykan dengan current ratio (CR), dimana merupakan perbandingan antara aktiva lancar terhadap hutang lancer, variabel bebas kedua (X2) berupa kebijakan hutang yang di proxykan dengan debt to equty ratio, variabel bebas ketiga berupa pertumbuhan perusahaan (X3) yang tergambar melalui besarnya pertumbuhan total aktiva (total aset) yang dihitung berdasarkan nilai aktiva periode tahun sekarang dikurangi dengan nilai aktiva periode tahun sebelumya dan dibagi dengan nilai aktiva periode tahun sebelumnya dan juga menggunakan variabel bebas size (ukuran) perusahaan yang merupakan nilai logaritma normal dari total penjualan, karena total aset sudah digunakan sebagai penghitung pertumbuhan perusahaan.

Penelitian ini juga menggunakan variabel intervening yakni return on equity (Y), yang merupakan hasil perbandingan antara nilai laba bersih terhadap modal sendiri. Penelitian ini juga menggunakan variabel terikat (Z) berupa nilai perusahaan yang diproxykan dengan price book value (PBV), yang merupakan hasil perbandingan antara harga saham terhadap nilai buku perusahaan (book value). Penelitian ini sebagai tindak lanjut dari penelitian terdahulu yang sudah ada seperti yang telah dilakukan oleh Amalia Nur Chasanah (2018) dengan judul Pengaruh Rasio Likuiditas, Profitabilitas, Struktur Modal dan Ukuran perusahaan pada perusahaan Manufaktur yang Terdaftar di BEI Tahun 2015-2017. Hasil penelitian menunjukkan bahwa secara parsial, ROA berpengaruh terhadap nilai perusahaan, sedangkan rasio likuiditas, struktur modal dan ukuran perusahaan yang diproksikan Current ratio, Debt to equity ratio dan Total Asset tidak berpengaruh terhadap nilai perusahaan. Secara Simultan, Current ratio, Debt to equity ratio, Total Asset dan Return On Asset berpengaruh secara bersama-sama terhadap nilai perusahaan. Tujuan penelitian ini adalah untuk menganalisis pengaruh likuiditas, kebijakan hutang, pertumbuhan perusahaan dan ukuran perusahaan melalui profitabilitas terhadap nilai perusahaan pada perusahaan sub sektor farmasi di Bursa Efek Indonesia periode 2014 - 2019.

\section{Landasan Teori}

Current ratio merupakan salah satu rasio yang mengukur likuiditas perusahaan. Menurut Sawir (2005) current ratio yang rendah menunjukkan adanya masalah dalam likuiditas perusahaan, demikian juga current ratio yang terlalu tinggi pun tidak menunjukkan bahwa perusahaan tersebut dalam kondisi yang baik, karena hal tersebut mengindikasikan kemampuan perusahaan dalam mendapatkan laba kurang maksimal terbukti dengan adanya akitivitas yang dilakukan oleh perusahaan sedikit atau produktivitas perusahaan yang lemah. Dampak dari produktifitas perusahaan yang lemah akan berpengaruh terhadap keuntungan yang akan diperoleh oleh perusahaan, sehingga profitabilitas perusahaan akan menurun, sehingga akan mempengaruhi nilai return on equity perusahaan yang juga akan semakin kecil. Jadi dapat disimpulkan bahwa current ratio berpengaruh terhadap profitabilitas yang dihasilkan oleh perusahaan yang tergambar melalui besaran nilai return on equity perusahaan.

Kebijakan hutang suatu perusahaan sangat penting bagi perusahaan, yang merupakan perbandingan antara hutang yang dimiliki perusahaan dengan modal maupun aktiva yang dimilikinya. Penelitian ini menggunakan debt to equity ratio sebagai proxy dari kebijakan hutang. Debt to equity ratio (DER) merupakan merupakan kelompok rasio solvabilitas yang menjadi salah satu variabel independen dalam penelitian ini. Nilai DER ditunjukan dengan total debts yang dibagi dengan nilai total sareholders equity. Semakin tinggi DER menunjukkan semakin besar total utang terhadap total ekuitas, hal ini juga akan menunjukkan semakin besar ketergantungan perusahaan terhadap pihak luar (kreditur) sehingga tingkat resiko perusahaan semakin besar. Menurut Brigham dan Houston (2006), semakin tinggi risiko dari penggunaan lebih banyak utang akan cenderung menurunkan harga saham sehingga akan mendorong turunnya kinerja pasar terhadap nilai bukunya. Investor perlu memperhatikan kesehatan perusahaan melalui perbandingan antara modal sendiri dan modal pinjaman. Jika modal sendiri lebih besar dari modal pinjaman, maka perusahaan tidak akan mudah bangkrut, Samsul ( 2006 : 204), sehingga akan mempengaruhi keuntungan yang akan diperoleh perusahaan baik jangka pendek maupun jangka panjangnya. Jadi dapat disimpulkan bahwa Debt to equity ratio berpengaruh terhadap profitabilitas perusahaan.

Likuiditas yang dimiliki oleh suatu perusahaan merupakan gambaran kemampuan perusahaan dalam memenuhi kewajiban jangka pendeknya. Likuiditas perusahaan dapat tergambar melalui besaran nilai current ratio nya. Current ratio yang rendah akan menurunkan harga saham perusahaan tersebut, karena investor akan memilih 
Suryanti, Arna Suryani dan Yunan Surono, Pengaruh Likuiditas, Kebijakan Hutang, Pertumbuhan Perusahaan dan Ukuran Perusahaan Terhadap Nilai Perusahaan dengan Profitabilitas Sebagai Variabel Intervening pada Perusahaan Sub Sektor Farmasi Di Bursa Efek Indonesia Periode 2014 - 2019

saham perusahaan yang memiliki tingkat likuiditas yang tinggi sehingga akan mendorong naiknya kinerja pasar terhadap nilai bukunya. Price book value merupakan salah satu variabel yang dipertimbangkan seorang investor dalam menentukan saham mana yang akan dibeli. Price book value menunjukkan seberapa besar nilai perusahaan dari apa yang telah atau sedang ditanamkan oleh pemilik perusahaan. Semakin tinggi rasio ini, maka semakin besar tambahan kekayaan yang dinikmati oleh pemilik perusahaan (Husnan dan Pudjiastuti, 2006). Prastowo dan Julianti (2005) menyatakan bahwa jika harga pasar berada di bawah nilai bukunya, investor memandang bahwa perusahaan tidak cukup potensial. Jika investor ragu terhadap propek suatu saham, maka banyak saham dijual pada harga di bawah nilai bukunya dan sebaliknya, jika investor yakin maka saham dijual dengan harga di atas nilai bukunya.Pertumbuhan (growth) adalah seberapa jauh perusahaan menempatkan diri dalam sistem ekonomi secara keseluruhan atau sistem ekonomi untuk industri yang sama. Pertumbuhan perusahaan merupakan kemampuan perusahaan untuk meningkatkan total aset yang dapat dipengaruhi oleh beberapa faktor, yaitu faktor eksternal, internal, dan pengaruh iklim industri (Herawati, 2013).

Moeljono (2005), mengemukakan bahwa pengukuran ukuran perusahaan dapat dilakukan dengan menghitung dari total aset, investasi, perputaran modal, alat produksi, jumlah pegawai, keluasan jaringan usaha, penguasaan pasar, output produksi, besaran nilai tambah, besaran pajak terbayarkan, dan seterusnya itu ternyata menjadi bayangan akan kenyataan bahwa korporasi memang identik dengan perusahaan besar. Kebijakan hutang suatu perusahaan dapat tergambar melalui besarnya nilai debt to equity ratio yang merupakan perbandingan antara besarnya hutang terhadap modal yang dimiliki oleh perusahaan. Semakin besar hutang yang dimiliki oleh perusahaan, maka akan meningkatkan resiko yang dimiliki oleh suatu perusahaan yang akan berdampak pada menurunnya harga saham perusahaan sehingga akan berdampak pada menurunnya nilai perusahaan tersebut dimata investor. Dengan demikian dapat disimpulkan bahwa besar kecilnya hutang yang dimiliki perusahaan akan mempengaruhi besar kecilnya nilai perusahaan, yang pada akhirnya akan mempengaruhi nilai pasar saham perusahaan bagi investor. Penelitian ini menggunakan debt to equity ratio sebagai proxy dari kebijakan hutang. Jadi dapat disimpulkan bahwa kebijakan hutang berpengaruh terhadap perubahan nilai perusahaan.

Profitabilitas merupakan kemempuan perusahaan untuk memperoleh laba, dimana penelitian ini menggunakan return on equity sebagai proxy dari profitabilias. Profitabilitas modal sendiri atau sering dinamakan rentabilitas usaha atau Return On Equity (ROE) adalah perbandingan antara jumlah laba yang tersedia bagi pemilik modal sendiri di satu pihak dengan jumlah modal sendiri yang menghasilkan laba.(Riyanto, 2011). Laba yang dihasilkan oleh suatu perusahaan dengan penggunaan modal sendiri akan mempengaruhi investor untuk memilih saham- saham yang menguntungkan sehingga akan memilih saham perusahaan yang memiliki laba yang tinggi, sehingga secara tidak langsung akan menaikkan harga saham di pasar. Kenaikan harga saham ini akan mendorong naiknya kinerja pasar terhadap nilai buku perusahaan yang terwakili oleh naiknya price book value. Jadi dapat disimpulkan bahwa return on equity berpengaruh terhadap perubahan nilai perusahaan.

\section{Hipotesis}

Hipotesis penelitian ini adalah:

1. Diduga likuiditas, kebijakan hutang, pertumbuhan perusahaan dan ukuran perusahaan berpengaruh signifikan terhadap profitabilitas pada perusahaan sub sektor farmasi di Bursa Efek Indonesia periode 2014 - 2019.

2. Likuiditas, kebijakan hutang, pertumbuhan perusahaan dan ukuran perusahaan berpengaruh signifikan terhadap nilai perusahaan pada perusahaan sub sektor farmasi di Bursa Efek Indonesia periode 2014 - 2019.

3. Profitabilitas berpengaruh terhadap nilai perusahaan pada perusahaan sub sektor farmasi di Bursa Efek Indonesia periode 2014 - 2019.

\section{Metode}

Penelitian ini dilakukan dengan menganalisis dan menginterpretasikan data dan informasi dalam penelitian dan untuk menjawab tujuan dalam penelitian ini maka digunakan pendekatan deskriptif verifikatif. Perhitungan penelitian ini menggunakan bantuan software microsoft Excell dan SPSS 22.0. Guna mengetahui besarnya pengaruh antar variabel independen terhadap variabel dependen dalam penelitian ini menggunakan Path Analysis. Metode statistika dengan analisis jalur digunakan untuk mengukur pola hubungan yang mengisyaratkan besarnya pengaruh beberapa variabel penyebab (eksogen) terhadap variabel akibat (endogen).

Pemilihan metode analisis jalur dilakukan dengan pertimbangan sebagai berikut :

a. Metode ini mampu memberikan kejelasan hubungan dan besaran antar variabel penelitian yang sangat berguna bagi upaya peneliti dalam mengupas secara lebih dalam berbagai variabel yang diteliti.

b. Analisis jalur cocok digunakan untuk menganalisis hubungan sebab akibat, baik untuk mengetahui pengaruh langsung maupun tidak langsung seperangkat variabel penyebab (variabel eksogen) terhadap variabel akibat (endogen), baik secara simultan maupun parsial. 
Suryanti, Arna Suryani dan Yunan Surono, Pengaruh Likuiditas, Kebijakan Hutang, Pertumbuhan Perusahaan dan Ukuran Perusahaan Terhadap Nilai Perusahaan dengan Profitabilitas Sebagai Variabel Intervening pada Perusahaan Sub Sektor Farmasi Di Bursa Efek Indonesia Periode 2014 - 2019

Analisis jalur ini mengikuti pola struktural atau disebut model struktural. Variabel penelitian adalah likuiditas (current ratio) sebagai (X1), kebijakan hutang (debt to equity ratio) sebagai (X2), ukuran perusahaan (Ln Total Aset) sebagai (X3) dan pertumbuhan perusahaan (perubahan penjualan) sebagai (X4) yang menjadi variabel independent, profitabilitas (return on asset) sebagai (Y) menjadi variabel intervening dan nilai perusahaan (price to book value) sebagai (Z) menjadi variabel dependen. Sedangkan variabel lain yang tidak diukur atau diteliti dan berpengaruh terhadap profitabilitas dan nilai perusahaan disebut sebagai variabel epsilon (ع). Adapun hubungan struktur lengkap pengaruh variabel likuiditas, kebijakan hutang, pertumbuhan perusahaan dan ukuran perusahaan terhadap nilai perusahaan dengan profitabilitas sebagai variabel intervening pada perusahaan sub sektor farmasi di Bursa Efek Indonesia periode 2014-2019., seperti terlihat pada gambar 2 berikut;

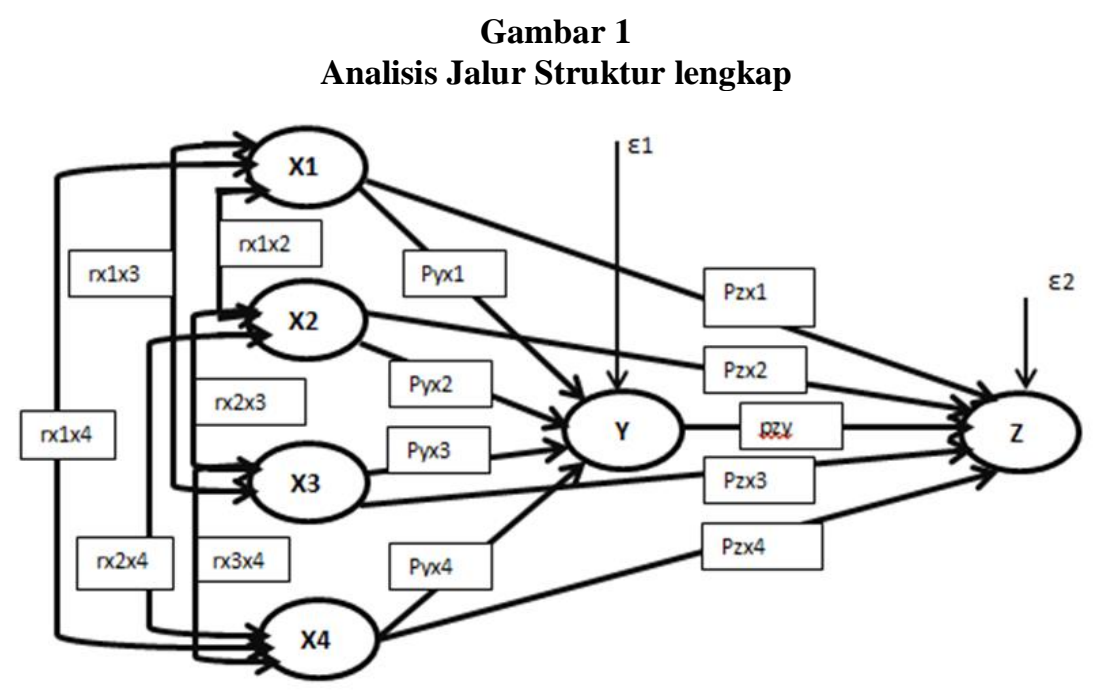

Guna mengetahui pengaruh variabel likuiditas, kebijakan hutang, pertumbuhan perusahaan dan ukuran perusahaan terhadap nilai perusahaan dengan profitabilitas sebagai variabel intervening.

- Pengaruh langsung: $\left(\mathrm{Pzx}_{1}\right)\left(\mathrm{Py}_{\mathrm{x} 1}\right)(\mathrm{Pzy})+\left(\mathrm{Pzx}_{2}\right)\left(\mathrm{Py}_{\mathrm{x} 2}\right)(\mathrm{Pzy})+\left(\mathrm{Pzx}_{3}\right)\left(\mathrm{Pyx}_{3}\right)(\mathrm{Pzy})+\left(\mathrm{Pz}_{4}\right)\left(\mathrm{Py}_{\mathrm{x}}\right)(\mathrm{Pzy})+\left(\mathrm{Pzx}_{2}\right)$ $\left(\mathrm{Py}_{2}\right)(\mathrm{Pzy})+\left(\mathrm{Pzx}_{3}\right)\left(\mathrm{Py}_{3}\right)(\mathrm{Pzy})+\left(\mathrm{Pz}_{4}\right)\left(\mathrm{Pyx}_{4}\right)(\mathrm{Pzy})$.

- Pengaruh tidak langsung: ( $\left.\mathrm{Pz}_{\mathrm{x} 1}\right)\left(\mathrm{Py}_{\mathrm{x} 1}\right)\left(\mathrm{r}_{\mathrm{x} 1 \mathrm{x} 2}\right)\left(\mathrm{Py}_{\mathrm{x} 2}\right)(\mathrm{Pzy})+\left(\mathrm{Pz}_{\mathrm{x} 1}\right)\left(\mathrm{Py}_{\mathrm{x} 1}\right)\left(\mathrm{r}_{\mathrm{x} 1 \mathrm{x} 3}\right)\left(\mathrm{Py}_{\mathrm{x} 3}\right)(\mathrm{Pzy})+\left(\mathrm{Pz}_{\mathrm{x} 1}\right)\left(\mathrm{Py}_{\mathrm{x} 1}\right)$ $\left(\mathrm{r}_{\mathrm{X} 1 \mathrm{x} 4}\right)\left(\mathrm{Pyx}_{4}\right)(\mathrm{Pzy})+\left(\mathrm{Pzx}_{2}\right)\left(\mathrm{Py}_{\mathrm{x} 2}\right)\left(\mathrm{r}_{\mathrm{X} 2 \mathrm{x} 1}\right)\left(\mathrm{Pyx}_{1}\right)(\mathrm{Pzy})+\left(\mathrm{Pzx}_{2}\right)\left(\mathrm{Py}_{\mathrm{x} 2}\right)\left(\mathrm{r}_{\mathrm{X} 2 \mathrm{x} 3}\right)\left(\mathrm{Py}_{\mathrm{x} 3}\right)(\mathrm{Pzy})+\left(\mathrm{Pzx}_{2}\right)\left(\mathrm{Py}_{\mathrm{x} 2}\right)\left(\mathrm{r}_{\mathrm{X} 2 \mathrm{x} 4}\right)$

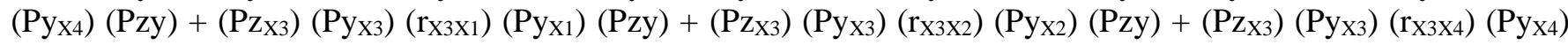

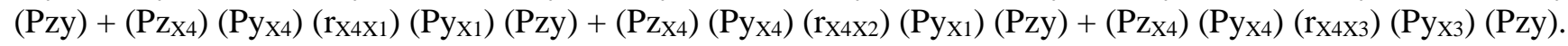

- Pengaruh total $=$ Pengaruh langsung + Pengaruh tidak langsung

\section{Hasil}

Gambar 2

Pengaruh Variabel X1, X2, X3 dan X4 terhadap Z melalui Y.

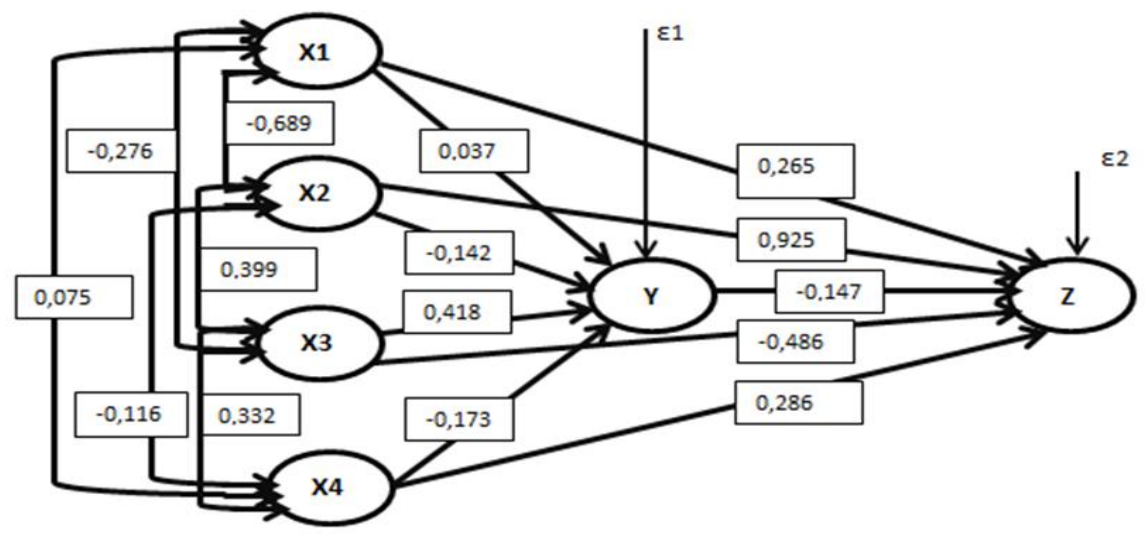

Besarnya engaruh variabel likuiditas, kebijakan hutang, pertumbuhan perusahaan dan ukuran perusahaan terhadap nilai perusahaan dengan profitabilitas sebagai variabel intervening antara lain; 
Suryanti, Arna Suryani dan Yunan Surono, Pengaruh Likuiditas, Kebijakan Hutang, Pertumbuhan Perusahaan dan Ukuran Perusahaan Terhadap Nilai Perusahaan dengan Profitabilitas Sebagai Variabel Intervening pada Perusahaan Sub Sektor Farmasi Di Bursa Efek Indonesia Periode 2014 - 2019

- Pengaruh langsung $=\left(\mathrm{Pzx}_{1}\right)\left(\mathrm{Py}_{\mathrm{x} 1}\right)(\mathrm{Pzy})+\left(\mathrm{Pzx}_{2}\right)\left(\mathrm{Py}_{\mathrm{x} 2}\right)(\mathrm{Pzy})+\left(\mathrm{Pzx}_{3}\right)\left(\mathrm{Pyx}_{3}\right)(\mathrm{Pzy})+\left(\mathrm{Pzx}_{4}\right)\left(\mathrm{Py}_{\mathrm{x}}\right)(\mathrm{Pzy})+\left(\mathrm{Pzx}_{2}\right)$ $\left(\mathrm{Py}_{\mathrm{x} 2}\right)(\mathrm{Pzy})+\left(\mathrm{Pz}_{\mathrm{x} 3}\right)\left(\mathrm{Py}_{\mathrm{x} 3}\right)(\mathrm{Pzy})+\left(\mathrm{Pz}_{\mathrm{x} 4}\right)\left(\mathrm{Pyx}_{4}\right)(\mathrm{Pzy})=0,265 \mathrm{x} 0,037 \mathrm{x}(0,147)+0,925 \mathrm{x}(0,142) \mathrm{x}(0,147)+$ $(0,486) \times 0,418 \times(0,147)+0,286 \times(0,173) \times(0,147)+0,925 \times(0,142) \times(0,147)+(0,486) \times 0,418 \times(0,147)+$ $0,286 \times(0,173) \times(0,147)=(0,0014)+0,0193+0,0298+0,0073+0,0193+0,0298+0,0073=0,1114=11,14 \%$ Pengaruh tidak langsung $=\left(\mathrm{Pz}_{\mathrm{X} 1}\right)\left(\mathrm{Py}_{\mathrm{x} 1}\right)\left(\mathrm{r}_{\mathrm{x} 1 \mathrm{x} 2}\right)\left(\mathrm{Py}_{\mathrm{x} 2}\right)(\mathrm{Pzy})+\left(\mathrm{Pz}_{\mathrm{X} 1}\right)\left(\mathrm{Py}_{\mathrm{x} 1}\right)\left(\mathrm{r}_{\mathrm{X} 1 \mathrm{x} 3}\right)\left(\mathrm{Py}_{\mathrm{X} 3}\right)(\mathrm{Pzy})+\left(\mathrm{Pz}_{\mathrm{x} 1}\right)\left(\mathrm{Py}_{\mathrm{x} 1}\right)$ $\left(\mathrm{r}_{\mathrm{X} 1 \mathrm{x} 4}\right)\left(\mathrm{Py}_{\mathrm{x} 4}\right)(\mathrm{Pzy})+\left(\mathrm{Pz}_{\mathrm{x} 2}\right)\left(\mathrm{Py}_{\mathrm{x} 2}\right)\left(\mathrm{r}_{\mathrm{X} 2 \mathrm{x} 1}\right)\left(\mathrm{Py}_{\mathrm{x} 1}\right)(\mathrm{Pzy})+\left(\mathrm{Pz}_{\mathrm{X} 2}\right)\left(\mathrm{Py}_{\mathrm{x} 2}\right)\left(\mathrm{r}_{\mathrm{X} 2 \mathrm{x} 3}\right)\left(\mathrm{Py}_{\mathrm{x} 3}\right)(\mathrm{Pzy})+\left(\mathrm{Pz}_{\mathrm{x} 2}\right)\left(\mathrm{Py}_{\mathrm{x} 2}\right)\left(\mathrm{r}_{\mathrm{X} 2 \mathrm{x} 4}\right)$

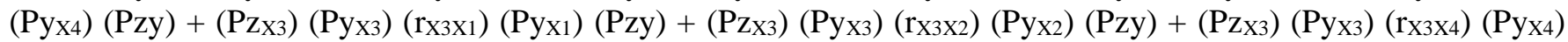
$(\mathrm{Pzy})+\left(\mathrm{Pz}_{\mathrm{X} 4}\right)\left(\mathrm{Py}_{\mathrm{X} 4}\right)\left(\mathrm{r}_{\mathrm{X} 4 \mathrm{x} 1}\right)\left(\mathrm{Py}_{\mathrm{X} 1}\right)(\mathrm{Pzy})+\left(\mathrm{Pz}_{\mathrm{X} 4}\right)\left(\mathrm{Py}_{\mathrm{X} 4}\right)\left(\mathrm{r}_{\mathrm{X} 4 \mathrm{X} 2}\right)\left(\mathrm{Py}_{\mathrm{X} 1}\right)(\mathrm{Pzy})+\left(\mathrm{Pz}_{\mathrm{X} 4}\right)\left(\mathrm{Py}_{\mathrm{X} 4}\right)\left(\mathrm{r}_{\mathrm{X} 4 \mathrm{X} 3}\right)\left(\mathrm{Py}_{\mathrm{X} 3}\right)\left(\mathrm{Pzy}_{2}\right)=$ $0,265 \times 0,037 \times(0,689) \times(0,142) \times(0,147)+0,265 \times 0,037 \times(0,276) 0,418 \times(0,147)+0,265 \times 0,037 \times 0,075 \times$ $(0,173) \times(0,147)+0,925 \times(0,142) \times(0,689) \times 0,037 \times(0,147)+0,925 \times(0,142) \times 0,399 \times 0,418 \times(0,147)+0,925$ $\mathrm{x}(0,142) \mathrm{x}(0,116) \mathrm{x}(0,173) \mathrm{x}(0,147)+(0,486) \times 0,418 \times(0,276) \times 0,037 \mathrm{x}(0,147)+(0,486) \times 0,418 \times 0,399 \mathrm{x}$ $(0,142) \times(0,147)+(0,486) \times 0,418 \times 0,332 \times(0,173) \times(0,147)+0,286 \times(0,173) \times 0,075 \times 0,037 \times(0,147)+0,286$ $\mathrm{x}(0,173) \times(0,116) \times 0,037 \times(0,147)+0,286(0,173) \times 0,332 \times 0,418 \times(0,147)=[(0,00014)+0,00016+0,000018$ ]$+[(0,00049)+0,00322+0,00038]+[(0,00030)+(0,00169)+(0,00171)]+[0,00002+(0,00003)+0,00100]=$ $0,000038+0,00311+(0,0037)+0,00099=0,000438=0,0438 \%$

Pengaruh total $=$ Pengaruh langsung + Pengaruh tidak langsung $=11,14 \%+0,0438 \%=11,1838 \%$

Pengaruh likuiditas, kebijakan hutang, pertumbuhan perusahaan dan ukuran perusahaan secara langsung dan tidak langsung terhadap profitabilitas pada perusahaan sub sektor farmasi di Bursa Efek Indonesia periode 2014 2019. Hasil penelitian terlihat secara simultan seluruh variabel bebas tidak berpengaruh signifikan terhadap variabel terikat pada $\alpha=5 \%$ atau 0,05 karena memiliki nilai sig 0,217 atau lebih besar dari 0,05 artinya tidak terdapat pengaruh signifikan secara simultan antara variabel independen likuiditas yang diproxykan dengan current ratio, kebijakan hutang yang diproxykan dengan debt to equity ratio, pertumbuhan perusahaan yang diproxykan dengan perubahan total aset dan ukuran perusahaan yang diproxykan dengan logaritma normal (Ln) penjualan terhadap profitabilitas yang diproxykan dengan return on equity. Pengujian simultan (uji F) diperoleh bahwa nilai F-hitung terhadap $\mathrm{F}$ tabelnya sebesar $(1,508<2,43)$, sehingga dapat disimpulkan bahwa secara simultan variabel bebas (independent) tidak berpengaruh terhadap variabel terikat (dependent). Besaran nilai koefisien determinasi berganda $\mathrm{R}^{2}$ yang memberikan gambaran seberapa besar proporsi atau presentase sumbangan variabel-variabel bebas (independent variable) secara bersama-sama terhadap perubahan yang terjadi pada variabel terikat (dependent variable), sehingga dapat dijelaskan bahwa variabel likuiditas, kebijakan hutang, pertumbuhan perusahaan dan ukuran perusahaan mempunyai pengaruh sebesar $12,3 \%$ terhadap profitabilitas.

Berikut ini dapat dijelaskan pengaruh langsung dan tidak langsung variabel independen penelitian terhadap variabel dependen (ROE);

a. Pengaruh langsung variabel X1 terhadap $\mathrm{Y}$ sebesar 0,0014 atau $0,14 \%$ sedangkan pengaruh tidak langsung X1 melalui X2 terhadap Y sebesar $(0,0036)$ atau $(0,36) \%$, pengaruh tidak langsung X1 melalui X3 terhadap Y sebesar $(0,00426)$ atau $(0,42) \%$, pengaruh tidak langsung X1 melalui X4 terhadap Y sebesar $(0,00048)$ atau $(0,048) \%$. Data tersebut menunjukkan bahwa jika profitabilitas mengalami kenaikan 1 satuan maka likuiditas akan mempunyai pengaruh langsung dengan mengalami kenaikan sebesar $0,14 \%$, jika profitabilitas mengalami kenaikan 1 satuan maka akan berpengaruh tidak langsung dengan kenaikan sebesar $0,36 \%$ terhadap variabel likuiditas melalui kebijakan hutang. Jika profitabilitas mengalami kenaikan 1 satuan maka akan berpengaruh tidak langsung dengan penurunan sebesar $(0,42) \%$ terhadap variabel likuiditas melalui pertumbuhan perusahaan. Jika profitabilitas mengalami kenaikan 1 satuan maka akan berpengaruh tidak langsung dengan penurunan sebesar $(0,048) \%$ terhadap variabel likuiditas melalui ukuran perusahaan. Nilai total pengaruh langsung dan tidak langsung variabel X1 terhadap Y sebesar 0,026\%, artinya pengaruh variabel likuiditas mempunyai pengaruh sebesar 0,026\% terhadap profitabilitas.

b. Pengaruh langsung variabel X2 terhadap $\mathrm{Y}$ sebesar 0,0201 atau 2,01\% sedangkan pengaruh tidak langsung X2 melalui X1 terhadap Y sebesar 0,0036 atau 0,36\%, pengaruh tidak langsung X2 melalui X3 terhadap Y sebesar $(0,0236)$ atau $(2,36) \%$, pengaruh tidak langsung X2 melalui X4 terhadap Y sebesar $(0,00285)$ atau $(0,285) \%$. Data tersebut menunjukkan bahwa jika profitabilitas mengalami kenaikan 1 satuan maka kebijakan hutang akan mempunyai pengaruh langsung dengan mengalami kenaikan sebesar 2,01\%, jika profitabilitas mengalami kenaikan 1 satuan maka akan berpengaruh tidak langsung dengan kenaikan sebesar 0,36\% terhadap variabel kebijakan hutang melalui likuiditas. Jika profitabilitas mengalami kenaikan 1 satuan maka akan berpengaruh tidak langsung dengan penurunan sebesar $(2,36) \%$ terhadap variabel kebijakan hutang melalui pertumbuhan perusahaan. Jika profitabilitas mengalami kenaikan 1 satuan maka akan berpengaruh tidak langsung dengan penurunan sebesar $(0,285) \%$ terhadap variabel kebijakan hutang melalui ukuran perusahaan. Nilai total pengaruh langsung dan tidak langsung variabel X1 terhadap Y sebesar 0,275\%, artinya pengaruh variabel kebijakan hutang mempunyai pengaruh sebesar $0,275 \%$ terhadap profitabilitas. 
Suryanti, Arna Suryani dan Yunan Surono, Pengaruh Likuiditas, Kebijakan Hutang, Pertumbuhan Perusahaan dan Ukuran Perusahaan Terhadap Nilai Perusahaan dengan Profitabilitas Sebagai Variabel Intervening pada Perusahaan Sub Sektor Farmasi Di Bursa Efek Indonesia Periode 2014 - 2019

c. Pengaruh langsung variabel $\mathrm{X} 3$ terhadap $\mathrm{Y}$ sebesar 0,1747 atau $17,47 \%$ sedangkan pengaruh tidak langsung X3 melalui X1 terhadap Y sebesar $(0,0042)$ atau $(0,42) \%$, pengaruh tidak langsung X3 melalui X2 terhadap Y sebesar $(0,0236)$ atau $(2,36) \%$, pengaruh tidak langsung X3 melalui X4 terhadap Y sebesar $(0,0240)$ atau $(2,40) \%$, Data tersebut menunjukkan bahwa jika profitabilitas mengalami kenaikan 1 satuan maka pertumbuhan perusahaan akan mempunyai pengaruh langsung dengan mengalami kenaikan sebesar $17,47 \%$, jika profitabilitas mengalami kenaikan 1 satuan maka akan berpengaruh tidak langsung dengan penurunan sebesar $(0,42) \%$ terhadap variabel pertumbuhan perusahaan melalui likuiditas. Jika profitabilitas mengalami kenaikan 1 satuan maka akan berpengaruh tidak langsung dengan penurunan sebesar $(2,36) \%$ terhadap variabel pertumbuhan perusahaan melalui kebijakan hutang. Jika profitabilitas mengalami kenaikan 1 satuan maka akan berpengaruh tidak langsung dengan penurunan sebesar $(2,40) \%$ terhadap variabel pertumbuhan perusahaan melalui ukuran perusahaan. Nilai total pengaruh langsung dan tidak langsung variabel X3 terhadap Y sebesar 12,29\%, artinya pengaruh variabel pertumbuhan perusahaan mempunyai pengaruh sebesar 12,29\% terhadap profitabilitas.

d. Pengaruh langsung variabel X4 terhadap Y sebesar 0,0299 atau 2,99\% sedangkan pengaruh tidak langsung X4 melalui X1 terhadap Y sebesar $(0,0004)$ atau $(0,04) \%$, pengaruh tidak langsung X4 melalui X2 terhadap Y sebesar $(0,0028)$ atau $(0,28) \%$, pengaruh tidak langsung X4 melalui X3 terhadap Y sebesar $(0,0240)$ atau $(2,40) \%$. Data tersebut menunjukkan bahwa jika profitabilitas mengalami kenaikan 1 satuan maka ukuran perusahaan akan mempunyai pengaruh langsung dengan mengalami kenaikan sebesar $17,47 \%$, jika profitabilitas mengalami kenaikan 1 satuan maka akan berpengaruh tidak langsung dengan penurunan sebesar $(0,04) \%$ terhadap variabel ukuran perusahaan melalui likuiditas. Jika profitabilitas mengalami kenaikan 1 satuan maka akan berpengaruh tidak langsung dengan penurunan sebesar $(0,28) \%$ terhadap variabel ukuran perusahaan melalui kebijakan hutang. Jika profitabilitas mengalami kenaikan 1 satuan maka akan berpengaruh tidak langsung dengan penurunan sebesar $(2,40) \%$ terhadap variabel ukuran perusahaan melalui ukuran perusahaan. Nilai total pengaruh langsung dan tidak langsung variabel X4 terhadap Y sebesar $0,27 \%$, artinya pengaruh variabel pertumbuhan perusahaan mempunyai pengaruh sebesar $0,27 \%$ terhadap profitabilitas.

Pengaruh likuiditas, kebijakan hutang, pertumbuhan perusahaan dan ukuran perusahaan secara langsung dan tidak langsung terhadap nilai perusahaan pada perusahaan sub sektor farmasi di Bursa Efek Indonesia periode 2014 2019. Hasil penelitian terlihat secara simultan seluruh variabel bebas berpengaruh signifikan terhadap variabel terikat pada $\alpha=5 \%$ atau 0,05 karena memiliki nilai sig 0,000 atau lebih kecil dari 0,05 artinya terdapat pengaruh signifikan secara simultan antara variabel independen likuiditas yang diproxykan dengan current ratio, kebijakan hutang yang diproxykan dengan debt to equity ratio, pertumbuhan perusahaan yang diproxykan dengan perubahan total aset dan ukuran perusahaan yang diproxykan dengan logaritma normal $(\mathrm{Ln})$ penjualan terhadap nilai perusahaan yang diproxykan dengan price to book value. Pengujian simultan (uji F) diperoleh bahwa nilai F-hitung lebih besar dari Ftabelnya $(9,789>2,43)$, sehingga dapat disimpulkan bahwa secara simultan variabel bebas (independent) berpengaruh terhadap variabel terikat (dependent). Nilai koefisien determinasi berganda $\mathrm{R}^{2}$ yang memberikan gambaran seberapa besar proporsi atau presentase sumbangan variabel-variabel bebas (independent variable) secara bersama-sama terhadap perubahan yang terjadi pada variabel terikat (dependent variable), sehingga dapat dijelaskan bahwa variabel likuiditas, kebijakan hutang, pertumbuhan perusahaan dan ukuran perusahaan mempunyai pengaruh sebesar 47,7\% terhadap nilai perusahaan.

Berikut ini dapat dijelaskan pengaruh langsung dan tidak langsung variabel independen penelitian terhadap variabel dependen (ROE);

a. Pengaruh langsung variabel $\mathrm{X} 1$ terhadap $\mathrm{Z}$ sebesar 0,0702 atau $7,02 \%$ sedangkan pengaruh tidak langsung $\mathrm{X} 1$ melalui X2 terhadap Z sebesar $(0,1689)$ atau $(16,89) \%$, pengaruh tidak langsung X1 melalui X3 terhadap Z sebesar 0,0355 atau 3,55\%, pengaruh tidak langsung X1 melalui X4 terhadap Z sebesar 0,00568 atau 0,57\%. Data tersebut menunjukkan bahwa jika nilai perusahaan mengalami kenaikan 1 satuan maka likuiditas akan mempunyai pengaruh langsung dengan mengalami kenaikan sebesar 7,02\%, jika nilai perusahaan mengalami kenaikan 1 satuan maka akan berpengaruh tidak langsung dengan penurunan sebesar $(16,89) \%$ terhadap variabel likuiditas melalui kebijakan hutang. Jika nilai perusahaan mengalami kenaikan 1 satuan maka akan berpengaruh tidak langsung dengan kenaikan sebesar 3,55\% terhadap variabel likuiditas melalui pertumbuhan perusahaan. Jika nilai perusahaan mengalami kenaikan 1 satuan maka akan berpengaruh tidak langsung dengan kenaikan sebesar 0,57\% terhadap variabel likuiditas melalui ukuran perusahaan. Nilai total pengaruh langsung dan tidak langsung variabel X1 terhadap Y sebesar $(5,75) \%$, artinya pengaruh variabel likuiditas mempunyai pengaruh sebesar $(5,75) \%$ terhadap nilai perusahaan.

b. Pengaruh langsung variabel $\mathrm{X} 2$ terhadap $\mathrm{Z}$ sebesar 0,8556 atau 85,56\% sedangkan pengaruh tidak langsung X2 melalui X1 terhadap Z sebesar $(0,1689)$ atau $(16,89) \%$, pengaruh tidak langsung X2 melalui X3 terhadap Z sebesar $(0,1794)$ atau $(17,94) \%$, pengaruh tidak langsung X2 melalui X4 terhadap Z sebesar $(0,0307)$ atau $(3,07) \%$. Data tersebut menunjukkan bahwa jika nilai perusahaan mengalami kenaikan 1 satuan maka kebijakan hutang akan 
Suryanti, Arna Suryani dan Yunan Surono, Pengaruh Likuiditas, Kebijakan Hutang, Pertumbuhan Perusahaan dan Ukuran Perusahaan Terhadap Nilai Perusahaan dengan Profitabilitas Sebagai Variabel Intervening pada Perusahaan Sub Sektor Farmasi Di Bursa Efek Indonesia Periode 2014 - 2019

mempunyai pengaruh langsung dengan mengalami kenaikan sebesar $85,56 \%$, jika nilai perusahaan mengalami kenaikan 1 satuan maka akan berpengaruh tidak langsung dengan penurunan sebesar $(16,89) \%$ terhadap variabel kebijakan hutang melalui likuiditas. Jika nilai perusahaan mengalami kenaikan 1 satuan maka akan berpengaruh tidak langsung dengan penurunan sebesar $(17,94) \%$ terhadap variabel kebijakan hutang melalui pertumbuhan perusahaan. Jika nilai perusahaan mengalami kenaikan 1 satuan maka akan berpengaruh tidak langsung dengan penurunan sebesar $(3,07) \%$ terhadap variabel kebijakan hutang melalui ukuran perusahaan. Nilai total pengaruh langsung dan tidak langsung variabel X1 terhadap Z sebesar 47,66\%, artinya pengaruh variabel kebijakan hutang mempunyai pengaruh sebesar $47,66 \%$ terhadap nilai perusahaan.

c. Pengaruh langsung variabel X3 terhadap $\mathrm{Z}$ sebesar 0,2362 atau 23,62\% sedangkan pengaruh tidak langsung X3 melalui X1 terhadap $\mathrm{Z}$ sebesar 0,0355 atau 3,55\%, pengaruh tidak langsung X3 melalui X2 terhadap Z sebesar $(0,1794)$ atau $(17,94) \%$, pengaruh tidak langsung X3 melalui X4 terhadap Z sebesar $(0,0461)$ atau $(4,61) \%$. Data tersebut menunjukkan bahwa jika nilai perusahaan mengalami kenaikan 1 satuan maka pertumbuhan perusahaan akan mempunyai pengaruh langsung dengan mengalami kenaikan sebesar 23,62\%, jika nilai perusahaan mengalami kenaikan 1 satuan maka akan berpengaruh tidak langsung dengan kenaikan sebesar 3,55\% terhadap variabel pertumbuhan perusahaan melalui likuiditas. Jika nilai perusahaan mengalami kenaikan 1 satuan maka akan berpengaruh tidak langsung dengan penurunan sebesar $(17,94) \%$ terhadap variabel pertumbuhan perusahaan melalui kebijakan hutang. Jika nilai perusahaan mengalami kenaikan 1 satuan maka akan berpengaruh tidak langsung dengan penurunan sebesar $(4,61) \%$ terhadap variabel pertumbuhan perusahaan melalui ukuran perusahaan. Nilai total pengaruh langsung dan tidak langsung variabel $\mathrm{X} 3$ terhadap $\mathrm{Z}$ sebesar 4,62\%, artinya pengaruh variabel pertumbuhan perusahaan mempunyai pengaruh sebesar 4,62\% terhadap nilai perusahaan.

d. Pengaruh langsung variabel X4 terhadap $\mathrm{Z}$ sebesar 0,0818 atau 8,18\% sedangkan pengaruh tidak langsung X4 melalui X1 terhadap $\mathrm{Z}$ sebesar 0,0056 atau $0,56 \%$, pengaruh tidak langsung $\mathrm{X} 4$ melalui $\mathrm{X} 2$ terhadap $\mathrm{Z}$ sebesar $(0,0307)$ atau $(3,07) \%$, pengaruh tidak langsung X4 melalui X3 terhadap Z sebesar $(0,0461)$ atau $(4,61) \%$. Data tersebut menunjukkan bahwa jika nilai perusahaan mengalami kenaikan 1 satuan maka ukuran perusahaan akan mempunyai pengaruh langsung dengan mengalami kenaikan sebesar $8,18 \%$, jika nilai perusahaan mengalami kenaikan 1 satuan maka akan berpengaruh tidak langsung dengan kenaikan sebesar $0,56 \%$ terhadap variabel ukuran perusahaan melalui likuiditas. Jika nilai perusahaan mengalami kenaikan 1 satuan maka akan berpengaruh tidak langsung dengan penurunan sebesar $(3,07) \%$ terhadap variabel ukuran perusahaan melalui kebijakan hutang. Jika nilai perusahaan mengalami kenaikan 1 satuan maka akan berpengaruh tidak langsung dengan penurunan sebesar $(4,61) \%$ terhadap variabel ukuran perusahaan melalui pertumbuhan perusahaan. Nilai total pengaruh langsung dan tidak langsung variabel $\mathrm{X} 4$ terhadap $\mathrm{Z}$ sebesar $1,06 \%$, artinya pengaruh variabel pertumbuhan perusahaan mempunyai pengaruh sebesar $1,06 \%$ terhadap nilai perusahaan.

Pengaruh profitabilitas terhadap nilai perusahaan pada perusahaan sub sektor farmasi di Bursa Efek Indonesia periode 2014 - 2019. Pengujian parsial (uji - t) diperoleh bahwa t- hitung < t-tabel yakni $(-1,007<1,681)$, maka profitabilitas tidak berpengaruh terhadap nilai perusahaan yakni sebesar -1,007 atau dapat juga dilihat dari nilai sig.nya yang di atas 0,05 atau 5\% yakni sebesar 0,319 atau 31,9\%., serta dapat dilihat dari pengaruh langsung variabel profitabilitas terhadap nilai perusahaan yaitu sebesar 0,0216 atau 2,16\%. Jadi dapat disimpulkan bahwa hipotesis ke tiga ditolak, yang berarti tidak ada pengaruh signifikan profitabilitas (ROR) terhadap nilai perusahaan (PBV).

Pengaruh likuiditas, kebijakan hutang, pertumbuhan perusahaan dan ukuran perusahaan melalui profitabilitas terhadap nilai perusahaan pada perusahaan sub sektor farmasi di Bursa Efek Indonesia periode 2014 - 2019. Dari hasil penelitian dapat dilihat bahwa variabel likuiditas, kebijakan hutang, pertumbuhan perusahaan dan ukuran perusahaan terhadap nilai perusahaan dengan profitabilitas sebagai variabel intervening adalah;

a. Variabel X1, X2, X3 dan X4 ke Z melalui Y, mempunyai pengaruh langsung sebesar 0,1114 atau sebesar 11,14\% dan pengaruh tidak langsung sebesar 0,000438 atau sebesar $0,0438 \%$, pengaruh total keseluruhan yaitu sebesar $11,1838 \%$, hal ini menunjukkan bahwa jumlah pengaruh total variabel X1, X2, X3 dan X4 terhadap Z melalui Y sebesar $11,1838 \%$, yang merupakan penggabungan keseluruhan struktur lengkap dari masing-masing jalur yang ada, baik dari struktur 1, 2, dan 3 .

b. Struktur I yang mana merupakan pengaruh variabel X1, X2, X3 dan X4 ke Y yakni pengaruh antara variabel likuiditas (current ratio), kebijakan hutang (debt to equity ratio), pertumbuhan perusahaan (Ln total asset) dan ukuran perusahaan (perubahan penjualan) terhadap profitabilitas (return on asset) mempunyai total pengaruh sebesar $12,3 \%$ yang berarti sisanya sebanyak $87,7 \%$ dipengaruhi oleh faktor lainnya. Makna dari hasil penelitian ini menggambarkan bahwa pada sub sektor farmasi jika terjadi kenaikan sebesar 1 satuan (1 persen) pada return on asset maka akan terjadi perubahan total terhadap current ratio, debt to equity ratio, Ln total asset dan perubahan penjualan sebesar $12,3 \%$ dengan rincian current ratio sebesar $0,026 \%$, debt to equity ratio sebesar $0,275 \%$, Ln total asset sebesar $12,29 \%$ dan perubahan penjualan sebesar $0,27 \%$. Perhitungan tersebut menggambarkan bahwa ukuran perusahaan (perubahan penjualan) mempunyai pengaruh dan kontribusi terbesar terhadap profitabilitas 
Suryanti, Arna Suryani dan Yunan Surono, Pengaruh Likuiditas, Kebijakan Hutang, Pertumbuhan Perusahaan dan Ukuran Perusahaan Terhadap Nilai Perusahaan dengan Profitabilitas Sebagai Variabel Intervening pada Perusahaan Sub Sektor Farmasi Di Bursa Efek Indonesia Periode 2014 - 2019

(return on asset), yang berarti setiap terjadi kenaikan sebesar 1\% pada ROA maka akan terjadi kenaikan sebesar $12,29 \%$ pada total aset demikian juga sebaliknya. Selanjutnya, pengaruh dan kontribusi debt to equity ratio dan perubahan penjualan terhadap profitabilitas (return on asset) mempunyai pengaruh sebesar $0,27 \%$, yang berarti setiap terjadi kenaikan sebesar $1 \%$ pada return on asset maka akan terjadi kenaikan sebesar $0,27 \%$ pada debt to equity ratio dan penjualan. Selanjutnya, pengaruh dan kontribusi likuiditas (current ratio) terhadap profitabilitas (return on asset) mempunyai pengaruh sebesar $0,026 \%$, yang berarti setiap terjadi kenaikan sebesar $1 \%$ pada return on asset maka akan terjadi kenaikan sebesar $0,026 \%$ pada sub sektor farmasi.

c. Struktur II yang mana merupakan pengaruh variabel X1, X2, X3 dan X4 ke Z yakni pengaruh antara variabel likuiditas (current ratio), kebijakan hutang (debt to equity ratio), pertumbuhan perusahaan (Ln total asset) dan ukuran perusahaan (perubahan penjualan) terhadap nilai perusahaan (price to book value) mempunyai total pengaruh sebesar 47,6\% yang berarti sisanya sebanyak 52,4\% dipengaruhi oleh faktor lainnya. Makna dari hasil penelitian ini menggambarkan bahwa pada sub sektor farmasi jika terjadi kenaikan sebesar 1 satuan (1 persen) pada price to book value maka akan terjadi perubahan total terhadap current ratio, debt to equity ratio, Ln total asset dan perubahan penjualan sebesar $47,6 \%$ dengan rincian current ratio sebesar $(5,75) \%$, debt to equity ratio sebesar 47,66\%, Ln total asset sebesar 4,62\% dan perubahan penjualan sebesar 1,06\%. Perhitungan tersebut menggambarkan bahwa kebijakan hutang (debt to equity ratio) mempunyai pengaruh dan kontribusi terbesar terhadap nilai perusahaan (price to book value), yang berarti setiap terjadi kenaikan sebesar $1 \%$ pada price to book value maka akan terjadi kenaikan sebesar $47,66 \%$ pada debt to equity ratio demikian juga sebaliknya. Selanjutnya, pengaruh dan kontribusi Ln total asset terhadap nilai perusahaan (price to book value) mempunyai pengaruh sebesar 4,62 \%, yang berarti setiap terjadi kenaikan sebesar $1 \%$ pada price to book value maka akan terjadi kenaikan sebesar 4,62\% pada total aset. Selanjutnya, pengaruh dan kontribusi perubahan penjualan terhadap nilai perusahaan (price to book value) mempunyai pengaruh sebesar 1,06 \%, yang berarti setiap terjadi kenaikan sebesar $1 \%$ pada price to book value maka akan terjadi kenaikan sebesar $1,06 \%$ pada penjualan. Selanjutnya, pengaruh dan kontribusi current ratio terhadap nilai perusahaan (price to book value) mempunyai pengaruh sebesar $(5,75) \%$, yang berarti setiap terjadi kenaikan sebesar $1 \%$ pada price to book value maka akan terjadi penurunan sebesar $1,06 \%$ pada current ratio sub sektor farmasi.

d. Struktur III yang mana merupakan pengaruh variabel $\mathrm{Y}$ ke $\mathrm{Z}$ yakni pengaruh antara profitabilitas (return on asset) terhadap nilai perusahaan (price to book value) mempunyai pengaruh sebesar $2,16 \%$ yang berarti sisanya sebanyak 97,84 \% dipengaruhi oleh faktor lainnya. Makna dari hasil penelitian ini menggambarkan bahwa pada sub sektor farmasi jika terjadi kenaikan sebesar 1 satuan (1 persen) pada price to book value maka akan terjadi kenaikan sebesar $2,16 \%$ pada return on asset.

\section{Simpulan}

Penelitian ini diperoleh berdasarkan analisis terhadap hasil penelitian telah dijelaskan pada bab sebelumnya, maka dapat ditarik kesimpulan yaitu:

1. Variabel independen likuiditas yang diproxykan dengan current ratio, kebijakan hutang yang diproxykan dengan debt to equity ratio, pertumbuhan perusahaan yang diproxykan dengan perubahan total aset dan ukuran perusahaan yang diproxykan dengan logaritma normal (Ln) penjualan terhadap profitabilitas yang diproxykan dengan return on equity, secara simultan seluruh variabel bebas tidak berpengaruh segnifikan terhadap variabel terikat sedangkan bahwa secara parsial hanya variabel pertumbuhan perusahaan yang diproxykan dengan perubahan total aset yang berpengaruh terhadap variabel profitabilitas.

2. variabel independen likuiditas yang diproxykan dengan current ratio, kebijakan hutang yang diproxykan dengan debt to equity ratio, pertumbuhan perusahaan yang diproxykan dengan perubahan total aset dan ukuran perusahaan yang diproxykan dengan logaritma normal (Ln) penjualan terhadap nilai perusahaan yang diproxykan dengan price to book value, secara simultan seluruh variabel bebas berpengaruh signifikan terhadap variabel terikat sedangkan secara parsial hanya variabel pertumbuhan perusahaan yang diproxykan dengan perubahan total aset yang tidak berpengaruh terhadap variabel nilai perusahaan.

3. Variabel profitabilitas yang diproxykan dengan return on equity tidak berpengaruh terhadap variabel nilai perusahaan yang diproxykan dengan price to book value.

4. Variabel likuiditas yang diproxykan dengan current ratio, kebijakan hutang yang diproxykan dengan debt to equity ratio, pertumbuhan perusahaan yang diproxykan dengan perubahan total aset dan ukuran perusahaan yang diproxykan dengan logaritma normal ( $\mathrm{Ln})$ penjualan terhadap nilai perusahaan yang diproxykan dengan price to book value dengan profitabilitas yang diproxykan dengan return on equity sebagai variabel intervening mempunyai pengaruh total sebesar $11,1838 \%$, yang besar pengaruhnya termasuk lemah. 
Suryanti, Arna Suryani dan Yunan Surono, Pengaruh Likuiditas, Kebijakan Hutang, Pertumbuhan Perusahaan dan Ukuran Perusahaan Terhadap Nilai Perusahaan dengan Profitabilitas Sebagai Variabel Intervening pada Perusahaan Sub Sektor Farmasi Di Bursa Efek Indonesia Periode 2014 - 2019

\section{Daftar Pustaka}

Abdullah, Faisal.M. (2004). Dasar-dasar Manajemen Keuangan. Penerbit Universitas Muhammadiah Malang, Malang.

Brigham, F Eugene dan Joul F Houston. (2006), Dasar-Dasar Manajemen Keuangan, Edisi Kesepuluh,Salemba Empat,Jakarta.

Chasanah, Amalia Nur., (2018). Pengaruh Rasio Likuiditas, Profitabilitas, Struktur Modal dan Ukuran perusahaan pada perusahaan Manufaktur yang Terdaftar Di BEI Tahun 2015-2017. Jurnal Penelitian Ekonomi dan Bisnis, Vol. 3 (1). pp 39 - 47.

Elton, E.J, and Grubber, (1995), Modern Portfolio Theory and Invesment Analysis 5th ed, John Wiley \& Sons, New York.

Eskilani. El Cindy, Zainul Kisman \& Ni Nyoman Sawitri, (2019), Effect of Liquidity Ratio, Solvability, Asset Growth and Inflation on Stock Return with Profitability as Intervening Variable at Building Construction Sector in Indonesian Stock Exchange: A Review of Theories and Evidence. Archives of Business Research.Vol.7, No.8

Fahmi, Irham. (2012). Analisis Kinerja Keuangan, Bandung: Alfabeta.

(2012), Manajemen Investasi, Jakarta: Salemba Empat

(2014). Pengantar Manajemen Keuangan, Bandung: Alfabeta.

Ferdinand, Augusty (2006). Metode Penelitian Manajemen: Pedoman Penelitian untuk skripsi, Tesis dan Disertai Ilmu Manajemen. Semarang: Universitas Diponegoro.

Ghozali Imam. (2009). Aplikasi Analisis Multivariate dengan Program SPSS. Penerbit: Universitas Dipenogoro. Semarang,

. (2013). Aplikasi Analisis Multivariate dengan Program IBM SPSS 21 Update PLS Regresi. Semarang:

Badan Penerbit Universitas Diponegoro.

Hartono, Agus. 2010. Manajemen Keuangan. Edisi keempat. Yogyakarta : BPFE.

Hanafi, Mahduh dan Abdul Halim, (2012), Analisis Laporan Keuangan. Yogyakarta: (UPP) STIM YKPN.

Hasan, Iqbal, (2009), Analisis Data Penelitian Dengan Statistik, Bumi Aksara, Jakata.

Husnan, Suad. (2011), Dasar-Dasar Manajemen Keuangan, unit Penerbit dan Pencetakan (UPP)-AMP ,YKPN, Yogyakarta.

Husnan, S. dan E. Pudjiastuti. (2012). Dasar-dasar Manajemen Keuangan. Edisi Keenam. Cetakan Pertama. Yogyakarta: UPP STIM YPKN.

Ikatan Akuntan Indonesia. (2017). Standar akuntansi keuangan per efektif 1 januari. Jakarta: Ikatan Akuntan Indonesia.

Irawati, Susan, (2006), Manajemen Keuangan, Cetakan Kesatu, Bandung, Pustaka.

Jogiyanto, (2010), Analisis Investasi dan Teori Portofolio, Gajah Mada Press, Yogyakarta.

Jumingan, (2009), Analisis Laporan Keungan, Bumi Aksara, Jakarta.

Kamaludin, dan Rini Indriani. (2012). Manajemen keuangan. Edisi Revisi. CV. Bandar Maju. Bandung.

Kasmir, (2009). Pengantar Manajemen Keuangan Edisi Kedua, Jakarta : Kencana Prenada Media Group. (2008), Analisis Laporan Keuangan, PT RAJAGRAFINDO PERSADA, Jakarta.

(2014), Analisis Laporan Keuangan, Edisi Satu. Cetakan ketujuh. Jakarta: PT Raja Grafindo Perkasa.

Khalwaty, Tajul. (2000). Inflasi dan Solusinya. Jakarta: PT. Gramedia Pustaka Utama.

Martono dan Harjito (2008)., Manajemen Keuangan, Yogyakarta, Ekonisia.

Misran, Medy \&Mohammad Chabachib, (2017), Analisis pengaruh DER, CR dan TATO, Terhadap PBV Dengan ROA sebagai variabel Intervening (Studi Pada Perusahaan Properti dan real Estate yang Terdaftar di BEI tahun 2011-2014. Jurnal Diponegoro Journal Of management, Vol 6, No 1, pp 1-13.

Moeljono, Djokosantoso (2005), Good Corporate Culture Sebagai Inti Good Corporate Governance, Jakarta; Elex Media Computindo.

Munawir. S, (2007), Analisa Laporan Keuangan, Yogyakarta: Liberty.

Nafisah, Nila Izatun, (2018), Analisis pengaruh Return On Asset (ROA), Debt to Equity Rati (DER), Current Ratio (CR). Return On Equity (ROE), Price Earning Ratio (PER), Total Asset Turnover (TATO) dan Earning Per Share (EPS), Terhadap Nilai Perusahaan Manufaktur yang Terdaftar Di BEI Tahun 2014-2015. Jurnal Riset Mahasiswa Akuntansi, Vol 6, No 2, pp 1-17.

Prakoso, Prio Galih Raga \& Mochammad Chabachib, (2016), Analisis Pengaruh Current ratio, Size, Debt to Equity Ratio dan Total Asset Turnover Terhadap Dividend Yield Dengan Return On Asset Sebagai Variabel Intervening. Jurnal Diponegoro Journal Of management, Vol 5, No 2, pp 1-14.

Prastowo dan Julianty, (2005), Analisis Laporan Keuangan : Konsep dan Manfaat. Yogayakarta : AMP-YKPN.

Prihadi, Toto. (2011). Analisis Laporan Keuangan Teori dan Aplikasi Jakarta: PPM 
Suryanti, Arna Suryani dan Yunan Surono, Pengaruh Likuiditas, Kebijakan Hutang, Pertumbuhan Perusahaan dan Ukuran Perusahaan Terhadap Nilai Perusahaan dengan Profitabilitas Sebagai Variabel Intervening pada Perusahaan Sub Sektor Farmasi Di Bursa Efek Indonesia Periode 2014 - 2019

Raharja Putra, Hendra S, (2011). Buku Panduan Praktis Manajemen Keuangan dan Akuntansi untuk Eksekutif Perusahaan, Cetakan Pertama. Salemba Empat. Jakarta.

Rahayu, Maryati dan Sari, Bida. (2018). Faktor-faktor yang Mempengaruhi Nilai Perusahaan. Ikraith-Humaniora.

Reschiwati, R., Syahdina, A., Handayani, S. (2020), Effect of Liquidity, Profitability, and Size of Companies on Firm Value. Utopía y Praxis Latinoamericana, 25(Esp.6), Julio-Septiembre.

Riyanto, Bambang. (2010). Dasar-dasar Pembelajaran Perusahaan. BPFE. Yogyakarta.

Ryan dan Miyosi (2013), Membuat Laporan Keuangan Gampang, Penerbit Dunia Cerdas, Jakarta.

Samsul, Mohammad, (2006), Pasar Modal Dan Manajemen Portofolio, Erlangga, Jakarta.

Salainti, Mirza Laili Inoditia, (2019), Pengaruh Current Ratio, Total asset Turnover, Debt to Equity Ratio Dan Return On Asset, Terhadap Nilai Perusahaan. Jurnal Ilmu dan Riset Manajemen.

Sartono, R Agus, (2001), Manajemen Keuangan: Teori dan Aplikasi, Edisi 4 BPFE, Jogjakarta.

Scott, W. R. (2015). Financial accounting theory (7th ed.). USA: Prentice-Hall.

Sinaga, F.F. \& Matrodji Mustafa. (2019). Analisis Pengaruh Kebijakan Hutang, Kebijakan Deviden, Dan Pertumbuhan Perusahaan Terhadap Nilai Perusahaan Dengan Profitabilitas Sebagai Variabel Intervening Pada Perusahaan Pembiayaan Yang Terdaftar di Bursa Efek Indonesia. Jurnal Penelitian Bisnis dan Manajemen. Vol 13 No 1. pp 43 -51.

Sondakh, Renly. (2019), The Effect Of Dividend Policy, Liquidity, Profitability And FirmSize On Firm Value In Financial Service Sector Industries Listed In Indonesia Stock Exchange 2015-2018 Period. Accountability Vol. 08, No. 02, pp. 91-101.

Suandy, Erly. (2008). Perencanaan pajak edisi 4. Jakarta: Penerbit Salemba Empat

Sudana, I Made. (2011). Manajemen Keuangan Perusahaan Teori dan Praktik, ERLANGGA, Surabaya.

Sugiyono. (2010). Metode Penelitian Kuantitatif, Kualitatif dan R\&D. Penerbit Alfabeta, Bandung. , (2013). Metode Penelitian Manajemen. Penerbit: Afabeta, Bandung.

Suharli, M. (2006). Studi Empiris terhadap Faktor yang Mempengaruhi Nilai Perusahaan pada Perusahaan Go Public di Indonesia. Jurnal Maksi VI (1)

Sulistyanto, H. S. (2008). Manajemen laba teori \& model empiris. Jakarta: Grasindo.

Tandelilin, Eduardus, (2001), Analisis Investasi dan Manajemen Portofolio, BPFE, Yogyakarta. , (2010), Analisis Investasi dan Manajemen Portofolio, BPFE, Yogyakarta.

Undang-undang nomor 8 Tahun 1995 tentang Pasar Modal.

Utari, Dewi, dkk. (2014). Manajemen Keuangan : Kajian Praktik dan Teori dalam Mengelola Keuangan Organisasi Perusahaan. Jakarta : Mitra Wacana Media.

Sawidji Widoatmodjo. (2008). Cara Sehat Investasi di Pasar Modal. Edisi Revisi. Jakarta: PT Elex Media Komputindo,

Van Horne James C dan John M. (2009). Prinsip-prinsip Manajemen Keuangan. Jakarta : Salemba Empat

Weston, J Fred dan Copeland E Thomas. (1994), Manajemen Keuangan, Cetakan Kedelapan, Erlangga, Jakarta.

Zain, Mohammad. (2008). Manajemen perpajakan. Jakarta: Salemba Empat.

Zubir, Zalmi. (2011), Manajemen Portofolio: Penerapannya dalam Investasi Saham. Salemba Empat: Jakarta.. 